\title{
On the Development of the Spores of Helminthostachys zeylanica.
}

\author{
BV \\ RUDOLF BEER, B.SC.

\section{With Plates XI and XII.}

THE writings of Goebel ${ }^{1}$, Holtzman ${ }^{2}$, Campbell ${ }^{3}$, and Bower ${ }^{4}$ have 1 made us familiar with the early history of the sporangium of the Ophioglossaceae. The actual structure of the spore, however, and the later stages of development, leading up to the establishment of that structure, have, hitherto, only been very imperfectly described for any member of this Order. Recently the publication of two papers, by Cardiff $^{5}$ and Stevens ${ }^{6}$ respectively, have added considerably to our knowledge of certain stages in the history of the spores of Botrychium, but we are still far from having a complete account of even this genus.

Through the kindness of Prof. F. W. Oliver I have had the opportunity of examining a number of fertile spikes of Helminthostachys zeylanica which had been preserved in spirit.

Although many important cytological details can only be determined with certainty by the study of material which has been specially fixed for the purpose, it was thought that the following notes might not be without their interest.

The first stages in the development of the sporangium of Helminthostachys zeylanica have been followed by Bower, who found the sporangium to be derived from a single superficial cell.

The first periclinal division of the cell defines the sporogenous from the protective portions of the sporangium; 'the sporogenous mass

${ }^{1}$ Goebel, 'Beiträge zur vergleichenden Entwickelungsgeschichte der Sporangien,' Bot. Zeit. I880, Bd. xxxviii.

${ }^{2}$ Holtzman, 'On the apical growth of the stem and the development of the Sporangium of Botrychium Virginianum,' Bot. Gazette, $\mathrm{x} 89^{2}$, vol. xvii.

s Campbell, 'Mosses and Ferns,' 1895.

4 Bower, 'Studies in the Morphology of Spore-producing members,' II, 1896.

5 Cardiff, 'Development of Sporangium in Botrychium,' Bot. Gazette, May 19०5, vol. xxxix.

6 Stevens, 'Spore Formation in Botrychium Virginianum,' Annals of Botany, October I905, vol. xix.

[Annals of Botany, Vo1. XX. No. LXXVIII. April, 1906.] 
increases rapidly in bulk, whilst the cells surrounding the sporogenous mass, to the extent of several layers, assume the character of a tapetum which gradually becomes disorganised; finally the sporogenous cells separate and the majority of them divide into tetrads; but a considerable portion of them, scattered throughout the sporogenous mass, become disorganised without undergoing division; this is similar to what has been observed in the case of Ophioglossum ${ }^{1}$.'

My own observations begin with a stage at which the sporogenous cells have reached their full number, but in which the tapetum has not yet become disorganized (Pl. XII, Fig. I5). The tapetal layer is composed of radially elongated cells many of which have divided once or, more rarely, twice by periclinal divisions (Pl. XI, Fig. I, and Pl. XII, Fig. I5). In Botrychium Cardiff observed periclinal divisions to follow one another until the tapetum became four or five cells in thickness. Stevens, however, does not confirm this statement and finds the tapetal layer of $B$. virginianum to be, as a rule, two cells in thickness, which would be more nearly in accordance with what I have seen in Helminthostachys.

The membranes of the tapetal cells are delicate, but clearly give the reactions of both cellulose and pectose. In this feature the tapetum of Helminthostachys apparently differs from that of Botrychium, in which Stevens found each tapetal cell to be 'deliminated by a plasmatic membrane merely:' Although Cardiff does not actually describe the cell-walls of the tapetum, his words certainly imply the occurrence of a cell-wall other than a plasmatic membrane.

The sporogenous cells which lie within the tapetal layer are mostly square or oblong cells which measure about I2-I8 $\mu$ across (Figs. I6 and (7). Their walls give the characteristic pectic reactions, but neither cellulose nor callose is to be found in them. The cytoplasm of these cells is fairly dense and contains a number of plastids usually crowded with starch. In slightly older sporangia the tapetal walls begin to break down, and in these disorganizing membranes I no longer succeeded in obtaining the cellulose reactions, although pectose was still clearly demonstrable $^{2}$.

The cytoplasm derived from the disorganized cells flows together (Figs. 2 and 16 ) and increases in amount, whilst the nuclei, which are mostly gathered together in little nests or groups at the inner or outer periphery of the tapetal layer, have become more numerous. The groups of nuclei are no doubt partly formed by the approximation of nuclei from several disorganized cells, but there can be little doubt that they also represent, to some extent, a number of daughter-nuclei which have origin-

1 Spore-producing members, Part II, I 896 , p. 35 .

${ }^{2}$ I state this fact for what it is worth, although the failure of the cellulose reactions may be due to the increased difficulty of demonstration rather than to the real absence of this substance. 
ated from the amitotic division of one or more mother-nuclei. The occurrence of constricted nuclei, such as I have represented in Fig. 2, bears out this view. Neither here, nor at any subsequent stage, have I seen tapetal nuclei dividing by mitosis.

The tapetal cytoplasm at this stage contains a quantity of starch and, in iron-haematoxylin-bismarck-brown preparations, presents a finely vacuolated appearance.

Up to the present the sporogenous cells have been united together in one coherent mass, but now they show the first signs of separating from one another (Fig. I7). The separation takes place in 'blocks' quite comparable with those described by Cardiff in Botrychium 1. In Helminthostachys, as in Botrychium, the separation appears to take place approximately ' in the order in which the original walls were laid down in the archesporium and young sporogenous mass.' The nuclei of the sporogenous cells of Helminthostachys are still in the resting condition when the separation of the 'blocks' commences.

Delicate and undifferentiated as the walls of the sporogenous cells appear, they must nevertheless possess a greater complexity of structure than becomes apparent with our instruments, for during the process of the separation of the sporogenous cells from one another a middle lamella becomes mucilaginous and is finally dissolved, whilst a secondary thickening layer remains unaltered round each sporogenous cell. The entire sporogenous membrane, both before and after the mucilaginous alteration of the middle lamella, gives no other reactions than those of pectic bodies. If I understand Stevens correctly, he found the mother-cells of Botrychium to be demarcated from one another and from the tapetum by a delicate plasmatic membrane alone, but Cardiff's statements do not bear this out and it certainly does not apply to the mother-cells of Helminthostachys. The sporogenous cells now divide into the spore-tetrads.

In the first division of the spore-mother-cells the chromosomes (which presumably occur in the reduced number) are seen to be small in size and rather crowded upon the spindle (Fig. 3). I have not succeeded in accurately counting their number, but I should very roughly estimate this to be between forty and sixty. Stevens has not recorded the number of chromosomes which occur in Botrychium. The spindle was surprisingly well preserved in the alcohol material and could be seen to terminate in very sharp, almost acuminate apices at which no traces of centrosomes were ever observed. The spindle extends to the very periphery of the mothercell and is free from any radiations at its poles (Fig. 4). The daughternuclei, resulting from the first division, have in some of my preparations a curiously flattened, almost hemispherical shape when viewed in profile ${ }^{2}$ (Fig. 5). They appear, like those of Botrychium, to enter into a resting

1 Cardiff, l. c., p. $34^{2}$.
${ }^{2}$ Compare this with Stevens' Plate_XXIX,_Fig. 28. N 2 
stage before passing on to the second division. The spore-mother-cells do not divide simultaneously, but all stages of division can be found in one sporangium. A mother-cell with its nucleus in the prophases of the first division not uncommonly occurs side by side with one which has completed its second division and has already developed the tetrad- (specialmother-cell) walls. In Botrychium Cardiff found that the cells in the same 'block' are always in the same stage, but in Helminthostachys the separation of the mother-cells has, apparently, been more complete before they enter upon the maiotic divisions, so that they have reached greater independence from one another than is the case in Botrychium.

Bower found that a considerable proportion of sporogenous cells became disorganized without undergoing division. In Botrychium Cardiff found no such disorganization to occur, and my preparations of Helminthostachys are quite in accordance with his observations and show no abortion of mother-cells. When the two divisions of the mother-cell have been completed the four cells of the tetrad are enveloped by the tetrad-wall (special-mother-cell wall) (Fig. I8).

This membrane is very delicate and in this respect forms a striking contrast to the conspicuous tetrad-walls of nearly all the other plants that I have examined (e.g. Riccia, Anthoceros, Lycopodiaceae, Osmunda \&c.). It gives the pectic reactions very clearly, whilst several times I obtained a rather faint violet-pink reaction with calcium-chloride-iodine solution. For some unexplained reason the calcium-chloride-iodine solution does not always produce the same result; the tetrad-wall in some cases colouring violet-pink, in others yellow.

While we may, therefore, conclude with certainty that this wall contains pectose, we must leave it undecided whether or not this substance is accompanied by cellulose ${ }^{1}$. The young spore-membrane colours, although rather faintly, with bismarck-brown, methylene blue, and similar dyes, and appears to be more or less cuticularized from a very early stage. It is a new formation and is not derived from the transformation of the specialmother-cell wall, which can still be recognized outside the spore-membrane (Fig. 6). In the meanwhile the disorganization of the tapetal walls has become complete, whilst the tapetal cytoplasm, which now forms a sort of plasmodium around the sporogenous cells (Fig. I6), has increased considerably in amount. The numerous nuclei which it contains still tend to be aggregated in groups.

We now find the plasmodial envelope sending finger-like processes into the cavity of the sporangium between the separated sporogenous cells. These cytoplasmic processes spread further and further between the sporogenous cells, branching and anastomosing with one another and separating

1 No other cellulose reaction, but only the inconstant appearance of the violet-pink colour with calcium-chloride-iodine, was given by these walls. 
the young tetrads more and more completely from one another (Fig. I8). At first these plasmodial strands consist solely of cytoplasm, unaccompanied by nuclei, which remain in the peripheral envelope. Soon, however, we can observe the nuclei dipping into the broader arms of cytoplasm and making their way into the interior of the sporangial cavity. As the round or oval nucleus passes into the strand of cytoplasm it usually alters its shape and becomes drawn-out, often into a very fine point, at its anterior extremity (Fig. 7). It usually stains more deeply at this beak-like process than it does at its blunt, posterior end. As it moves further along the strand and passes between the spore-tetrads it not infrequently assumes an elongated form, sometimes almost justifying the term vermiform, until it temporarily comes to rest at this or that spot, when it reassumes a more iso-diametric shape. The tapetal plasma, which has a finely vacuolated structure in successful preparations, contains an abundant supply of starch. All the cells composing the walls of the sporangium are rich in starch; the membranes of these cells give the pectic and cellulose reactions. The spores remain associated together in groups of four throughout the greater part of their development. They now rapidly increase in size, but their walls remain very thin and the cytoplasm they enclose is scanty. In consequence of this the spores, at this stage, are nearly all collapsed in the alcohol material (Fig. I9). The young spores are tetrahedral in shape and the edges of those surfaces which adjoin one another in the neighbouring spores of a tetrad are raised up into ridges. In this way each spore develops three ridges upon its surface, and these ridges converge to a common point (Fig. 8, $a$ ).

Early in the history of the spore one can see that the sides of the tetrahedron which meet at the ridges are only very loosely joined together. The action of various reagents, and even the pressure of the microtome knife, often leaves the spore with three flaps entirely separated from one another at the ridges, as is shown in Fig. 8, $b$. The cuticularized wall of the spore now grows somewhat in thickness, and at about this time a new layer-the endospore-makes its appearance within it. This layer, which gives the reactions of a pectic body, can be traced as a continuous, although delicate, layer over the entire inner surface of the spore-wall.

In microtome sections which have passed through the apex ${ }^{1}$ of the spore we can trace a little process or fold of the endospore which has pushed between the ridges of the exospore and which reaches to the outer surface (Fig. 9). In spores measuring about $23 \mu$ across their longest diameter the exospore has become sufficiently thick to prevent the collapse of the spore in alcohol. The surface of the spore is still smooth and its protoplast poor in substance ${ }^{2}$.

\footnotetext{
1 Viz., the point at which the three ridges meet.

${ }^{2}$ It usually contains a very little starch, however.
} 
The further growth in thickness of the exospore continues to leave the fold of endospore uncovered at the apex of the spore. The smooth surface of the exospore now becomes slightly wavy in outline, and this soon leads to the formation of the reticular sculpture which is characteristic of the mature spore.

The fully grown spore measures, in section, about $33 \mu$ by $28 \mu$. The exospore is thicker at the apex than over the rest of the spore, but is perforated by a cleft through which the fold of endospore reaches the exterior. This cleft is particularly well seen after treatment with a mixture of sulphuric and chromic acids or with sulphuric acid alone, but it can be quite readily distinguished in sections which have been stained with methylene blue, or bismarck-brown without the previous action of acid. Chlor-zinc-iodine solution, to which more iodine than usual has been added, also very clearly shows the endospore-coloured brown-penetrating the exospore and reaching the exterior. The reticular sculpturing upon the surface of the exospore appears in section as a series of blunt processes with flattened summits (Figs. IO and I I). The protoplast of the spore has now become somewhat richer in substance and usually includes starch, but not in any quantity.

Nothing in the nature of an epispore is to be found in the spores of Helminthostachys. The exospore and, most probably, also the endospore are in the first place deposited by the secretory activity of the sporeprotoplast. There is no possibility of the former layer being derived from the transformation of part or all of the mother-cell-wall, since this at all times very delicate wall can still be distinguished, in apparently undiminished thickness, over the surface of the young exospore (Fig. 6).

The fact that the exospore and endospore are inseparably united together at first suggests the probability of the two layers being derived from the differentiation of an originally single, homogeneous membrane. As Fitting ${ }^{1}$ has already pointed out, however, the existence of a close fusion between two layers of a wall does not necessarily indicate their common origin by differentiation, and there are several well-known cases in which two lamellae are intimately bound together, but which unquestionably have been separately deposited by the cell-protoplast. In the present instance, moreover, it is difficult to understand how a cuticularized membrane can be so differentiated as to give rise to a pure pectic lamella on one of its faces. The development of the little fold of endospore at the apex of the spore is also more readily explained as a new formation than as a product of differentiation. Shortly after the exospore has been formed round the young spore and throughout the time that this layer is growing in thickness and in surface the tapetal plasmodium which envelops the spore-tetrads shows unmistakable signs of metabolic activity.

${ }^{1}$ H. Fitting, Bot. Zeitung, Bd. 1viii, 1900, p. I 26. 
It is impossible to escape the conclusion that this metabolism is concerned with the elaboration of material for the growth of the exospore. That such material must be forthcoming is of course obvious, and the two sources to which one naturally looks for this supply are the spore-protoplast on the one hand and the tapetum upon the other. In Helminthostachys (at least in my spirit material) the spore protoplast, after the first formation of the exospore, is very poor in substance, and it is very unlikely that it can furnish sufficient plastic material for the growth of the wall. When one turns to the tapetum, however, one finds here a gradual utilization of reserve-materials which can fully account for the substance which is being employed in the growth of the exospore. Moreover, if we deny that the tapetal material is being utilized for this purpose it is not easy to see what the fate of this substance may be. The growth of the wall of the sporangium is amply provided for by the reserve-materials contained in its cells, whilst the protoplasts of the spores do not increase in size or substance during this time, so that we are driven to associate the disappearance of starch and cytoplasm from the tapetum with the only other demonstrable utilization of material, viz., that which is adding to the size and thickness of the spore-coats.

It is impossible at present, however, to decide whether the material elaborated in the tapetum is directly built up in the spore-walls or whether it first passes, in a liquid form, into the spore-protoplast which, either with or without further elaboration, distributes it to the walls.

In view of the important part that the tapetal plasmodium plays in the growth of the spore-walls it will be necessary at this point to look more closely at its appearance and behaviour. We find that starch is abundant in the tapetal cytoplasm before the walls of the tapetum disorganize and that it continues to exist there in considerable quantities until the period during which the exospore undergoes its most active growth in thickness. During this time the tapetal plasma is either very poor in starch or, more often, this substance is quite absent from it. When the exospore has completed its growth in thickness and the spore-protoplast is about to add to its substance, starch can usually again be seen in the tapetal cytoplasm but never in quantities that can compare with those which occurred in the early stages of sporangial development.

The tapetal cytoplasm at first increases somewhat in amount (immediately after the disorganization of the tapetal cells), but during the later history of development it slowly but steadily decreases in quantity (compare Figs. I8, 19, and 20). Where it abuts upon a vacuole (such as that which encloses a spore or spore-tetrad) the cytoplast has a very clearly marked plasmatic membrane; elsewhere it is finely vacuolated in structure. It is the vacuolar cytoplasm which is gradually utilized in the metabolic processes of the plasmodium, and the plasmatic membranes, 
which limit neighbouring vacuoles in consequence approach one another more and more closely. In sporangia, shortly before their dehiscence, the vacuolar cytoplasm has almost completely disappeared, but the plasmatic membranes are still present between the spores (Fig. 20). These can then, in nearly all cases, be seen to be double in structure owing to the complete approximation of the plasmatic membrane of adjoining vacuoles ${ }^{1}$. Starch grains can not infrequently be seen flattened out between the two adpressed membranes and, at the angles formed by the meeting of several vacuoles, nuclei occur.

The nuclei show, at all stages, considerable variation in size, in form, and in character. In Botrychium Cardiff found that the nuclei underwent a very considerable increase in size during development; thus in young sporangia he gives their size as $8 \mu$, whilst at a later stage he found them to measure $15-20 \mu$. In Helminthostachys the general average of size of the tapetal nuclei appears to remain about the same at different periods of development.

(a) Tapetal cells still intact . . . . . $=13 \times 11 \mu$

(b) Young spores with thin, smooth exospore . . = $13.4 \times 10 \mu$

(c) Spores with immature sculpturing on exospore . $=12.6 \times 9.6 \mu$

(d) Spores just before dehiscence of sporangium $\quad=13 \times 1 \mathrm{I} \mu$.

The above figures are the averages calculated from a large number of countings and they show practically no alteration in the size of the tapetal nuclei.

The form of the nuclei is very various. In the tapetal cells before disorganization and in the tapetal plasmodium before this flows between the sporogenous cells the nuclei are more or less oval in shape. The peculiar alteration in form which they often undergo as they pass within the sporangial cavity has already been described. In the later periods of development these nuclei are sometimes oval or spherical in outline; often they are irregular in shape and occasionally their form is angular (Fig. I2). They possess, in most cases, a distinct nuclear membrane and are usually rich in chromatin; several nucleoli can generally be seen in each nucleus. The chromatic granules are often closely packed (and the nucleus in consequence deep-staining) in the smaller nuclei, whilst in the larger nuclei the chromatin-grains are frequently separated more widely from one another and the nucleus contains more non-staining material.

In Botrychium Cardiff found that 'as the spores commence to separate in the tetrad, the tapetal cytoplasm has entirely filled the sporangium and many of the nuclei have begun to disorganize, though they seem unusually persistent and many are found after the tetrad is fully formed. Later,

${ }^{1}$ In consequence of the entire disappearance of the vacuolar cytoplasm which separated them from one another at an earlier stage. 
when the spores are entirely separated and mature, the tapetum disappears.' In Helminthostachys the tapetum and tapetal nuclei are evidently more persistent than Cardiff found to be the case in Botrychium ${ }^{1}$. It has already been mentioned that the plasmatic membranes and many nuclei are still to be found between spores which are quite or nearly mature, and I have rarely found nuclei which were degenerating except in sporangia which were almost ready to dehisce. In such sporangia the majority of the nuclei stained intensely and were closely packed with chromatic granules, whilst here and there a nucleus was seen in which the nuclear membrane had disappeared and the granules were becoming dispersed (Fig. I3). Mitotic divisions of the tapetal nuclei were at no time seen.

Cardiff records frequent amitotic divisions of the tapetal nuclei of Botrychium, but Stevens was unable to confirm this observation.

In Helminthostachys I have found reason to believe that in the early stages of sporangial development, immediately after the tapetal membranes have disintegrated, the nuclei do multiply by direct division, but in older sporangia it is much more difficult to find any evidence of such divisions. Irregularities in outline, which sometimes lead to a more or less constricted shape, not uncommonly occur, but most of these are undoubtedly to be referred to those passing changes of form which are so frequently to be found in nuclei that are taking part in active metabolic processes. Occasionally these changes of form may actually lead to a division of the nucleus, but in my material this is certainly rare. An isolated instance of such a division is shown in Fig. I4. Very possibly the conditions which prevail at the time when the material is collected may exert an influence upon the tapetal nuclei and may explain the differences which occur in the accounts of Cardiff and Stevens.

The principal features, therefore, which the tapetal plasmodium presents during the period of exospore growth are $(\alpha)$ an almost or quite complete disappearance of starch, $(b)$ a gradual diminution of the finely vacuolar cytoplasm, and $(c)$ the richly chromatic nuclei which often show irregularities of outline.

These features, I think, bear out the view already expressed that the tapetal plasmodium is the centre of metabolic activities in which a substance is elaborated from the raw materials contained in the tapetum. For reasons already stated we may further conclude that this substance is, directly or indirectly, employed in the growth of the spore-wall. by him.

1 Stevens also records much greater persistence of the nuclei in the Botrychium examined 


\section{EXPLANATION OF PLATES XI AND XII}

Illustrating Mr. Beer's paper on the Spores of Helminthostachys.

\section{PLATE XI. DRAWINGS.}

Fig. I. Tapetal cells. $\times 660$

Fig. 2. Nest of nuclei lying at the inner periphery of the disintegrating tapetum. $a$, a constricted nucleus which is probably dividing amitotically. $\times 850$.

Fig. 3. Chromosomes during first division of the spore-mother-cell. $x$ I 100.

Fig. 4. Spindle and chromosomes during first division of the spore-mother-cell. $\times 850$.

Fig. 5. Daughter-nuclei resulting from first division of the spore-mother-cell. $\times$ I 100 .

Fig. 6. Tetrad showing the very young spore-wall (left white) surrounded by the specialmother-cell wall (drawn black). $\times 850$.

Fig. 7. Tapetal plasmodium. Nuclei passing into one of the cytoplasmic strands which reach into the interior of the sporangium. $\times 850$.

Fig. $8, a$ and $b$. Young spores. In $b$ the wall has separated into three flaps at the ridges. $\times 850$.

Fig. 9. Apex of young spore; showing little fold of endospore in section. $\times 85^{\circ}$.

Figs. IO and II. Nearly mature spores. Fig. Io looked at from above; Fig. II in section. Both $\times 85$.

Fig. I 2. Tapetal nuclei from a sporangium in which spores had thickened, but still smooth exospores. $\times 850$.

Fig. I3. Nuclei from tapetum of mature sporangitum.

Fig. I4. Nucleus from tapetal plasmodium of a sporangium in which the young spores were surrounded by a thin exospore. Amitosis (?) $\times 850$.

\section{PLATE XII. PHOTOGRAPHS.}

Fig. I5. Young sporangium; tapetal cells surrounding the spore-mother-cells. The break in the mass of mother-cells is caused in preparing the section and does not indicate a natural separation of these.

Fig. 16. Spore-mother-cells surrounded by the tapetal plasmodium. The tapetal membranes have all disintegrated.

Fig. I 7. Early stage in the separation of the spore-mother-cells from one another. T" : first lines of the mucilaginous degeneration of the middle lamellae are shown.

Fig. I8. The young tetrads (special-mother-cells) with tapetal plasmodium gradually flowing between them.

Fig. 19. Older stage, showing distribution of tapetal plasmodium between the spore-tetrads. The young spores have all collapsed in the alcohol.

Fig. 20. Almost mature spores. The plasmatic membranes of the tapetal plasma still surround the spores. The spores to the extreme right of the figure show the little fold of endospore penetrating the cleft in the apex of the exospore. 

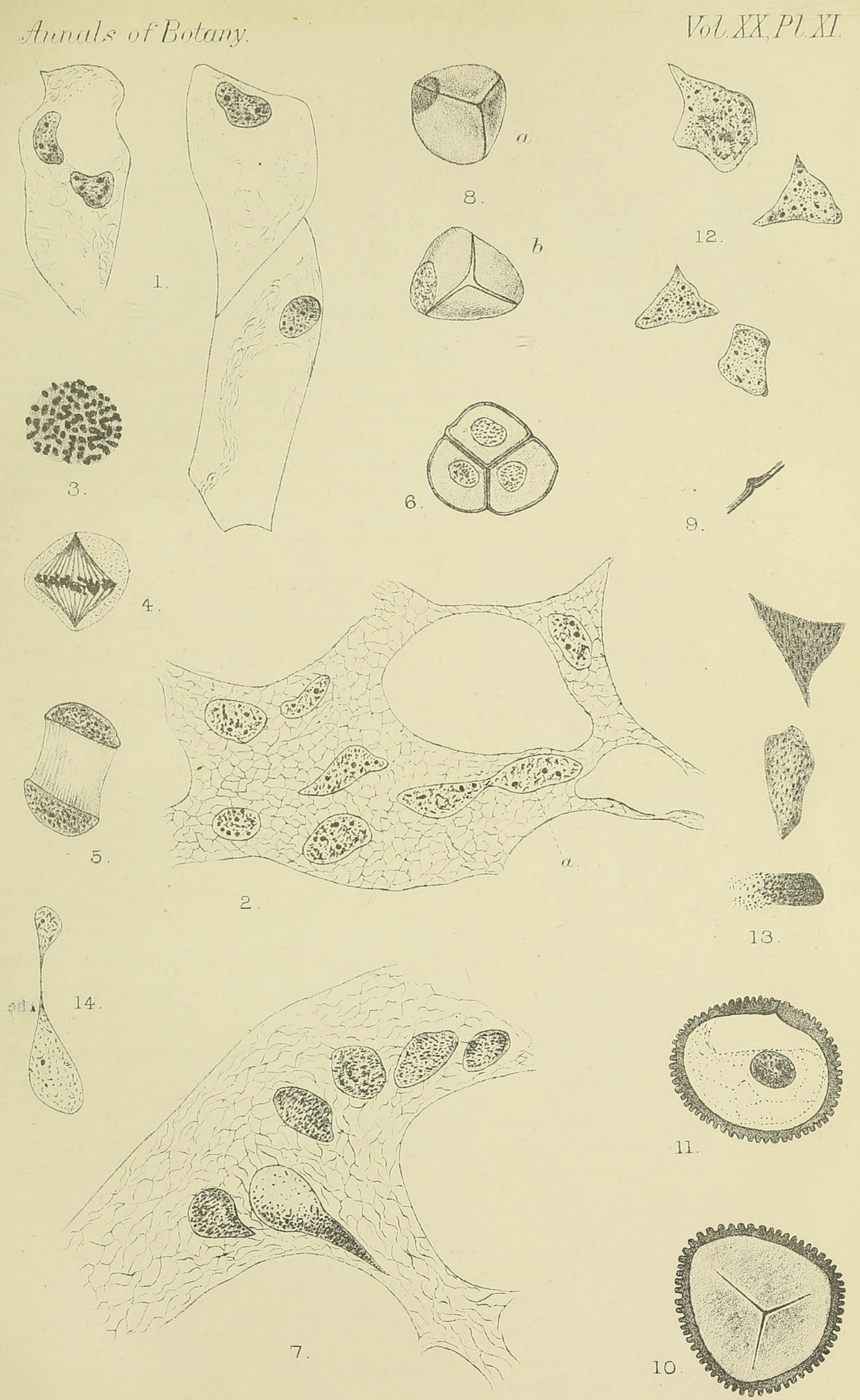

BEER - HELMINTHOSTACHYS. 


\section{$2 \mathrm{BHL}$ Biodiversity Heritage Library}

Beer, Rudolf. 1906. "On the development of the spores of Helminthostachys zeylanica." Annals of botany 20, 177-186.

https://doi.org/10.1093/oxfordjournals.aob.a089090.

View This Item Online: https://www.biodiversitylibrary.org/item/234848

DOI: https://doi.org/10.1093/oxfordjournals.aob.a089090

Permalink: https://www.biodiversitylibrary.org/partpdf/318830

\section{Holding Institution}

Smithsonian Libraries

\section{Sponsored by}

Biodiversity Heritage Library

\section{Copyright \& Reuse}

Copyright Status: Not in copyright. The BHL knows of no copyright restrictions on this item.

This document was created from content at the Biodiversity Heritage Library, the world's largest open access digital library for biodiversity literature and archives. Visit BHL at https://www.biodiversitylibrary.org. 